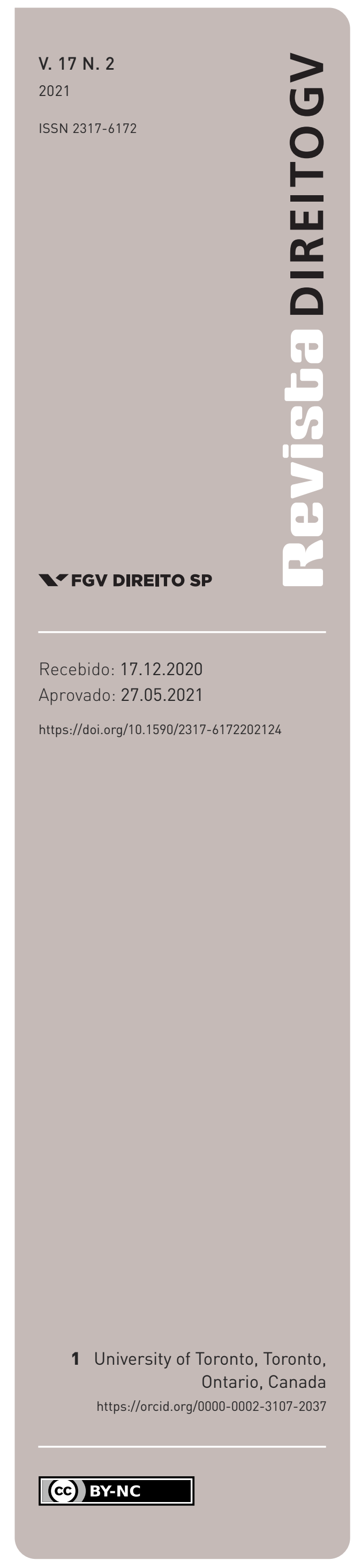

\title{
Law and Politics in FCPA Prosecutions of Foreign Corporations
}

LEI E POLÍTICA EM PROCESSOS DA FCPA CONTRA EMPRESAS ESTRANGEIRAS

\author{
Elizabeth Acorn ${ }^{1}$
}

\begin{abstract}
The expansive reach of US prosecutions addressing corporate and economic crimes has piqued the interest of many commentators and scholars. This is perhaps nowhere more evident than in the enforcement of the US Foreign Corrupt Practices Act ("FCPA") against non-American corporations. The US adopted the FCPA in 1977 to ban the payment of bribes to foreign public officials to obtain a business advantage-decades before most other countries did so and with jurisdiction over American and many foreign corporations. More than 40 years after the creation of the FCPA, this article reviews and outlines a growing interdisciplinary research agenda that considers historical, legal, and political influences on the application of the FCPA to foreign corporations. In addition to mapping the contours of this growing research agenda, the article identifies several challenges for such research and proposes potential avenues for future research that promise to deepen our understanding of why and when the US makes use of its expansive jurisdiction to prosecute foreign corporations for bribery of foreign public officials.
\end{abstract}

\section{Keywords}

Anti-corruption; FCPA; OECD Anti-Bribery Convention; transnational corporations; cross-border law enforcement.

\section{Resumo}

O amplo alcance dos processos nos Estados Unidos relativos a crimes corporativos e econômicos despertou o interesse de muitos comentaristas e acadêmicos. Isso talvez seja mais evidente na aplicação da Lei de Práticas de Corrupção no Exterior dos Estados Unidos ("FCPA") contra empresas não estadunidenses. Os Estados Unidos adotaram a FCPA em 1977 para proibir o pagamento de subornos, com o objetivo de obter vantagem comercial, a funcionários públicos estrangeiros - décadas antes da maioria dos outros países e com jurisdição sobre empresas estadunidenses e muitas empresas estrangeiras. Mais de quarenta anos após a criação da FCPA, este artigo analisa e descreve uma crescente agenda de pesquisa interdisciplinar que considera as influências históricas, jurídicas e políticas na aplicação da FCPA a empresas estrangeiras. Além de mapear os contornos dessa crescente agenda de pesquisa, identificam-se vários desafios para essa pesquisa e são propostos caminhos potenciais para pesquisas futuras que prometem aprofundar nossa compreensão de por que e quando os Estados Unidos fazem uso de sua jurisdição extensa para processar empresas estrangeiras por suborno de funcionários públicos estrangeiros.

\section{Palavras-chave}

Anticorrupção; FCPA; Convenção contra a Corrupção da OCDE; corporações transnacionais; aplicação da lei transfronteiriça. 


\section{INTRODUCTION}

Some of the most well-known cases under the Foreign Corrupt Practices Act ("FCPA") involve the prosecution of foreign corporations. The FCPA prohibits and punishes foreign bribery - the bribery of foreign government officials to obtain a business advantage. Foreign bribery, by definition, reaches outside of US territory. But US prosecutors frequently extend the FCPA's reach even further - not only policing conduct by Americans and American businesses that occurs largely outside of the US, but also prosecuting corporations incorporated in other countries. Commentators regularly note that several of the largest FCPA sanctions ever imposed are against foreign corporations (CASSIN, 2020b; PERLMAN and SYKES, 2018, p. 24). The Swedish company Ericsson, the Brazilian company Petrobras, and the Dutch/French company Airbus currently rank among the top FCPA penalties of all time, each having paid over a billion dollars to US authorities for the bribery of an array of public officials abroad (CASSIN, 2020a). The largest FCPA fine paid to date is from an American company, Goldman Sachs, but it is foreign corporations that make up the rest of the list of the top-ten FCPA fines (CASSIN, 2020a).

FCPA cases against foreign corporations have garnered significant attention with these headline-worthy settlement numbers and details of bribery by well-known companies. They have also begun to generate a research agenda, which this article reviews, on the expansive application of the FCPA and the conditions under which the US prosecutes foreign corporations for the bribery of foreign public officials. These far-reaching prosecutions are possible because of the wide reach of the FCPA, which prohibits bribery of public officials of other countries and related accounting practices and includes certain non-American businesses within its scope. But the fact that the FCPA establishes jurisdiction over foreign corporations tells us little about its use. The US is unique in its regular application of its anti-foreign bribery laws to foreign corporations. Moreover, this expansive application of domestic law is costly for the US, not only in the time and resource challenges of complex criminal investigation involving sophisticated actors, but also in the political risks of generating conflict with the home countries to foreign corporations that the US prosecutes. Together this raises the question of why and when a country would seek to apply its national laws to govern conduct by foreigners abroad.

This article begins with an introduction to the FCPA and its wide jurisdictional reach. Here I describe how the FCPA enables the US to prosecute foreign corporations for the bribery of foreign public officials and identify broad patterns in FCPA prosecutions of foreign corporations, including a notable uptick in such prosecutions starting in the early $21^{\text {st }}$ century. The article then turns in Section 2 to consider how existing scholarship can help us to understand the US use of the FCPA to govern foreign corporations. This section starts by reviewing scholarship that can explain the general US interest in the application of antiforeign bribery laws and why the US may be willing to take on the costs of investigating and prosecuting foreign corporations for their activities abroad. Section 2 then considers 
scholarship on the more granular question of why and when US prosecutors exercise jurisdiction over certain foreign corporations for FCPA violations. Scholarship is still developing on this question, but nonetheless has identified several potential explanations for what drives particular US FCPA prosecutions of foreign corporations. These potential explanations include using prosecutions of foreign corporations to spur anti-foreign bribery enforcement in a corporation's home state (KACZMAREK and NEWMAN, 2011), punish the most egregious violations of anti-bribery laws, or make up for institutional shortcomings of host states, including situations where systemic corruption precludes the functioning of local accountability institutions (CHOI and DAVIS, 2014; PRADO and PIMENTA, 2021).

After setting out the contours of this growing research agenda, I then turn to next steps for research, including identifying several important challenges of empirical research in this area. Here I identify measurement problems that are endemic to studying bribery in international business. I also discuss a conceptual issue of identifying what specifically constitutes the "foreign" prosecutions of interest and the challenge of studying prosecutorial decision-making. Finally, the article proposes several promising avenues for future research, and in particular calls for closer qualitative research and in-depth examination of how the actors tasked with applying the FCPA make decisions about whether and when to use the statute's expansive jurisdiction to prosecute foreign corporations for bribery abroad.

\section{BACKGROUND: The FCPA AND ITS EXPANSIVE APPLICATION}

As several scholars have recounted, the FCPA emerged in the aftermath of Watergate and the revelation that, in addition to making unlawful contributions to President Nixon's re-election campaign, American corporations were also regularly making questionable payments to government officials all over the world (see e.g. GUTTERMAN, 2015; SPAHN, 2013; KOEHLER, 2012). The FCPA was passed as part of the post-Watergate reforms and was the first law of its kind - in the US or elsewhere - that explicitly prohibited the payment of bribes to government officials of another country.

The US decision to go out on its own to prohibit foreign bribery appears to have been influenced by several factors. Ellen Gutterman argues that the context of post-Watergate America and "high public sensitivity to the norm against corruption" that the scandal had generated is critical to understand the US willingness to adopt the FCPA (GUTTERMAN, 2015, p. 110). Congressional debates in the lead-up to the adoption of the FCPA also reveal several important US interests that were being harmed by foreign bribery by US companies. The Secretary of Commerce set out the Ford Administration's interest in anti-foreign bribery legislation as follows: "What is at stake ultimately is confidence in, and respect for, American business, American institutions, American principles-indeed, the very democratic political values and free competitive economic system which we view as the essence of our most proud heritage and our most promising future" (RICHARDSON, 1976). Further, 
there was also concern that these payments to public officials of other countries could interfere with US foreign policy. As Senator Church, who served as the chair of the senate hearings that led up to the FCPA, explained: "US-based corporations should not be allowed to weaken a friendly government through bribery and corruption while the United States is relying on that government as a stable sure friend in supporting our policies" (KOEHLER, 2012, p. 941).

The US was not only the first country to prohibit foreign bribery, it was also a champion of the introduction of similar prohibitions in other countries. The US pressed for the creation of international legal obligations for states to prohibit foreign bribery, like we see in the OECD Anti-Bribery Convention and later the UN Convention Against Corruption (WOUTERS, RYNGAERT and CLOOTS, 2013; ABBOTT and SNIDAL, 2002). Today, the large majority of countries in the world have taken on an international obligation to prohibit and punish bribery in international business.

While national criminal prohibitions against foreign bribery are now common, the enforcement of these new laws has been another story. As Rachel Brewster and Christine Dryden write of the OECD Anti-Bribery Convention, "under-enforcement has become the state of affairs" (BREWSTER and DRYDEN, 2018, p. 239). Seventeen of the 44 state parties to the OECD Anti-Bribery Convention have yet to complete a single prosecution of foreign bribery (OECD 2020). In many of the OECD Anti-Bribery Convention countries that have begun to enforce their anti-foreign bribery laws, enforcement was slow to start and remains sporadic.

The US is a notable exception and is the global leader in the enforcement of anti-foreign bribery laws. Germany is second to the US, followed by the UK (OECD 2020). American prosecutors regularly complete dozens of FCPA actions per year (OECD 2020). This context of frequent American anti-foreign bribery enforcement and lackluster anti-foreign bribery enforcement in many countries is important to keep in mind as we now turn to consider the FCPA and its application to foreign corporations in more detail.

\section{A.The ReACh Ofthe FCPA: Application to Foreign Corporations}

The FCPA has two separate prongs to combat bribery in international business. First, the "anti-bribery provisions," which, stated generally, prohibit "paying bribes to foreign officials [...] for the purpose of obtaining a business benefit" (UROFSKY and MOON, 2013, p. 686). ${ }^{1}$ Second, the "accounting provisions" require that issuers - corporations with shares listed

1 The FCPA provides that it is unlawful "to make use of the mails or any means or instrumentality of interstate commerce corruptly in furtherance of an offer, payment, promise to pay, or authorization of the payment of any money, or offer, gift, promise to give, or authorization of the giving of anything of value to" 
on an American exchange-maintain accurate books and records and internal controls. ${ }^{2}$ Enforcement of the FCPA is shared by the Department of Justice ("DOJ") and the Securities and Exchange Commission ("SEC").

Foreign corporations, that is, corporations incorporated outside of the US, can be prosecuted for violations of either prong of the FCPA, if certain conditions are met. The FCPA's accounting provisions are limited to issuers, which includes many foreign corporations. The FCPA's anti-bribery provisions can apply to a foreign corporation if it is an issuer and it "make[s] use of the mails or any means or instrumentality of interstate commerce corruptly" (UROFSKY and MOON, 2013, p. 687). This interstate commerce requirement has been interpreted broadly to include "any interstate means of communication or any other interstate instrumentality," such as sending an e-mail, text message or wire transfer that crosses through the US (DIAMANT, SULLIVAN and SMITH, 2019, p. 361; DOJ and SEC, 2020).

In addition, a foreign corporation that does not qualify as an issuer can still be prosecuted for violating the anti-bribery provisions of the FCPA if it "either directly or through an agent, engage[s] in any act in furtherance of a corrupt payment [...] while in the territory of the United States" (DOJ and SEC, 2020; 15 U.S.C. $\$ 78 d d-3(a)$ ). This too has been interpreted broadly (DIAMANT, SULLIVAN and SMITH, 2019, p. 361). Foreign corporations that do not qualify as issuers have also been prosecuted under the FCPA's anti-bribery provisions as Coconspirators (DIAMANT, SULLIVAN and SMITH, 2019, p. 364). ${ }^{3}$ Altogether, the FCPA has an expansive reach: it prohibits payments made to public officials of other countries and related accounting practices and can punish non-American businesses that engage in such action and fall within the statute.

Prosecutors within the SEC and DOJ have wide latitude to determine whether to pursue foreign bribery cases (MCLEAN, 2012; KOEHLER, 2009). DOJ prosecutors are guided by the Principles of Federal Prosecution and the FCPA Corporate Enforcement Policy (DOJ and SEC, 2020, p. 50-51). The Principles of Federal Prosecution provide ample discretion to prosecutors

a "foreign official" or "foreign political party or official thereof" to "influence any act or decision [...] induce [...] [him or her] to act in violation of the lawful duty" or "secure an improper advantage" to aid "in obtaining or retaining business" (15 U.S.C. $\S \S 78 \mathrm{dd}-1$ (a)).

2 Specifically, the FCPA requires that issuers: "make and keep books, records, and accounts, which in reasonable detail, accurately and fairly reflect the transactions and dispositions of the assets of the issuer" and "devise and maintain a system of internal accounting controls sufficient to provide reasonable assurances" of the proper execution and recording of business transactions (15 U.S.C. $\S 78 \mathrm{~m}(\mathrm{~b})(2))$.

3 Note, however, that a recent decision of the Second Circuit limited the extent to which the FCPA applies to foreign nationals charged with conspiracy, requiring that the defendant be an agent of an entity subject to the FCPA or commit a wrongful act in US territory. United States v. Hoskins, 902 F.3d 69 (2d Cir. 2018). See also DIAMANT, SULLIVAN and SMITH, 2019, 364-365. 
to pursue an investigation or charges against a corporation, as well as determine the form of any resolution; these principles direct prosecutors to consider factors like "the nature and seriousness of the offense," the company's history of wrongdoing, and its remediation efforts (Justice Manual, S. 9-28.300). The FCPA Corporate Enforcement Policy outlines DOJ policy on declinations - a decision not to prosecute - which can be granted to a corporation that selfdiscloses the wrongdoing, cooperates with authorities, and remediates the harm. SEC prosecutors similarly consider factors like the gravity of the offense and the company's history of wrongdoing (DOJ and SEC, 2020, p. 54). The DOJ and SEC have jointly published two editions of A Resources Guide to the U.S. Foreign Corrupt Practices Act, which provide further details on the factors that US authorities consider in deciding whether to investigate or prosecute foreign bribery (DOJ and SEC, 2020). Still, even with these multiple policy documents, US prosecutors retain significant discretion over whether to pursue cases of foreign bribery, including when to prosecute foreign corporations for violations of the FCPA.

\section{B.The Rise in FCPA Prosecutions of Foreign Corporations}

The German company Siemens knows all too well how far the FCPA can reach. The company's $\$ 800$ million settlement with US authorities in 2008 for widespread practices of bribery abroad is an early and prominent FCPA prosecution of a foreign corporation. The parent corporation, Siemens AG, which had shares traded on a US stock exchange, fell under the FCPA's issuer jurisdiction and accepted a guilty plea for violating the FCPA's accounting provisions (DOJ 2008). Siemens subsidiaries entered guilty pleas for conspiring to violate the accounting provisions and anti-bribery provisions (DOJ 2008). The US action against Siemens was part

of a coordinated enforcement action with German prosecutors; all told, the company paid $\$ 1.6$ billion dollars in fines (DOJ 2008).

Siemens is far from alone. Other foreign corporations have also paid multimillion dollar, and even billion dollar, fines to US authorities for bribery of public officials of other countries (CASSIN, 2020a). By the end of 2018, over 100 foreign corporations had been prosecuted by US authorities for FCPA violations (CHRISTENSEN, MAFFETT and RAUTER, 2020, p. 7; DIAMANT, SULLIVAN and SMITH, 2019, p. 369-370). This phenomenon has increased over time: while rare in the $20^{\text {th }}$ century, US prosecutions of foreign corporations for FCPA violations are a common occurrence in the $21^{\text {st }}$ century (BREWSTER, 2017; CHRISTENSEN, MAFFETT and RAUTER, 2020).

Beyond the increase in the number of FCPA prosecutions of foreign corporations, there are several important trends in these prosecutions to note. Several commentators and scholars have pointed out the over-representation of foreign companies among the highest FCPA fines. As mentioned above, nine of the spaces on the current "Top Ten List of Corporate FCPA Settlements" are currently occupied by foreign corporations (CASSIN, 2020a). Further, research has shown that in general the fines paid by foreign corporations for FCPA violations tend to be higher (DIAMANT, SULLIVAN and SMITH, 2019, 355; CHOI and DAVIS, 2014). 
In addition, scholarship has documented geographic clusters in FCPA enforcement against foreign corporations. As Hans Christensen, Mark Maffett, and Thomas Rauter report in a recent paper, FCPA enforcement actions against foreign corporations "are essentially limited to firms headquartered in countries that have ratified the OECD Anti-Bribery Convention and that paid bribes in countries Transparency International classifies as 'highly corrupt" (CHRISTENSEN, MAFFETT and RAUTER, 2020, p. 3).

Of course, the international dimension of the FCPA has been clear from the outset: it is a statute that seeks to govern the conduct of business outside of the US, and creates a prohibition on foreign bribery that the US actively sought to extend globally. Nonetheless, this active enforcement of the FCPA against foreign corporations is still attention-grabbing. While some other OECD Convention countries can enforce their anti-foreign bribery prohibitions against foreign corporations operating in their jurisdictions, it is the US that most actively makes use of its expansive jurisdiction over foreign firms. Further, this expansive US enforcement is costly. The prosecution of any corporation for a complex crime like foreign bribery is difficult, requiring time and resources by police and prosecutors to marshal evidence of wrongdoing that involves public officials in another country. While some of these costs may be recovered through penalties paid by foreign corporations, there are still opportunity costs of focusing the attention of US prosecutors on foreign defendants. A prosecution of a foreign corporation can also bring political costs, running the risk of aggravating relationships with the corporation's home state or signaling the inhospitality of the US to foreign businesses. In short, it is far from obvious as to why the US would take on these costs to police conduct abroad by foreign companies.

One last important point to emphasize here is that the fact that the FCPA establishes jurisdiction over foreign corporations does not make the expansive use of the FCPA less noteworthy. Even with this broad jurisdictional mandate, the US has only actively enforced the FCPA against foreign corporations for the past 15 years. There's little reason to expect that foreign bribery occurred significantly less frequently in the $20^{\text {th }}$ century than today. As this suggests, there are very likely more instances of bribery abroad by foreign corporations than the US prosecutes, and the US is focusing its attention on particular cases of wrongdoing by foreign corporations. I turn now to explore existing research on the expansive enforcement of the FCPA and explanations that scholars have proposed for when we might expect to see US authorities prosecute foreign corporations for bribery abroad.

\section{Mapping the Research Agenda onthe Expansive Application ofthe FCPA}

There is a growing body of legal research that examines the extraterritorial application of US law to document and explore when and why the US deploys its national laws to govern conduct that occurs primarily abroad, including the conduct of non-Americans (see e.g. PUTNAM, 2009; RAUSTIALA, 2011; GARRETT, 2011; PUTNAM, 2016; KOH, 2019; 
VERDIER, 2020). In addition, a growing body of research in international relations under the umbrella of the "new interdependence approach" examines often-overlooked points of contact between states that are driven by domestic actors like prosecutors and regulators (FARRELL and NEWMAN, 2016; 2019; BACH and NEWMAN, 2014; EFRAT and NEWMAN, 2016; see also IRANI, 2020).

This section considers the expansive application of the FCPA within the context of these growing scholarly domains, examining how current scholarship accounts for the application of the FCPA to foreign corporations. It begins by reviewing scholarship that can help us understand the general US interest in the application of anti-foreign bribery laws to foreign corporations and why the US would ever be willing to incur the costs of policing the conduct of non-American businesses abroad. The discussion then turns to consider scholarship on the more specific question of why the US decides to exercise its expansive jurisdiction over foreign corporations for FCPA violations in particular cases. As the section details, scholarship on this more specific question is still emerging, but has nevertheless generated several explanations for what drives particular US prosecutions of foreign corporations for FCPA violations.

To start, existing scholarship on the origin and evolution of the FCPA provides important insight into why the US is interested at all in the prosecution of foreign corporations for the bribery of foreign public officials. As discussed in the previous section, there were multiple factors that led the US to go out on its own to prohibit foreign bribery and create the FCPA in 1977. But as soon as the new prohibition was created, it was immediately clear that simply prohibiting US businesses from engaging in foreign bribery would not, on its own, effectively address foreign bribery. As Daniel Tarullo points out using basic game theory, there are strong incentives for individual businesses to pay bribes to win business abroad (TARULLO, 2004, p. 699-700). ${ }^{4}$ Prohibiting only US companies from engaging in foreign bribery would not be enough to alter these incentives globally. In his statement on signing the FCPA into law, President Carter made this point clearly: the US "can only be fully successful in combatting bribery and extortion if other countries and business itself take comparable action" (CARTER, 1977).

Here the willingness of the US to apply the FCPA to bribery of foreign public officials by foreign corporations can be understood similarly to other expansive applications of US law. Research by Tonya Putnam finds that US courts are willing to apply US law extra-territorially when doing so helps to protect the functioning of a domestic regulatory regime

4 Tarullo explains that two companies bidding on the same contract are in a classic prisoner's dilemma; the dominant strategy is to defect and pay a bribe, given the absence of information as to whether the competitor will bribe (TARULLO, 2004, 699-700). 
(PUTNAM, 2009; 2016). Applied to the FCPA, the prosecution of foreign corporations would serve such an end: by targeting not only American, but also foreign wrongdoers, US prosecutors support the anti-bribery regulatory regime by reducing the incentives for businesses to engage in foreign bribery and protect markets from its distorting effects. This effort to support anti-bribery regulations and protect markets is how the DOJ has often described its enforcement of the FCPA against foreign corporations. For instance, Assistant Attorney General Lanny A. Breuer emphasized that prosecuting both domestic and foreign companies for FCPA violations is "vital to ensuring the integrity of our markets [...] [and] serves to make the international business climate more transparent and fair for everyone" (BREUER, 2010).

Research has also shown how the prosecution of foreign corporations mitigates opposition from American business to the FCPA with what Rachel Brewster describes as an "international-competition neutral enforcement strategy" (BREWSTER, 2017; see also PERLMAN and SYKES, 2018). Historically, many US businesses had opposed the FCPA, particularly during the more than two decades when the US stood alone in prohibiting foreign bribery (GUTTERMAN, 2015). Opponents to the FCPA argued that they faced a competitive disadvantage relative to their peers in other countries that faced no comparable national restriction of business abroad (GUTTERMAN, 2015; BREWSTER, 2017). Even when other countries did enact their own prohibitions against foreign bribery following the OECD Anti-Bribery Convention, US businesses arguably remained at a competitive disadvantage insofar as other states failed to enforce their own anti-foreign bribery rules. But, as Brewster points out, by putting the expansive jurisdictional basis of the FCPA into action and deploying an "internationalcompetition neutral enforcement strategy" that targeted both US and non-US corporations, US prosecutors can demonstrate that it is not only US businesses that face a meaningful risk of prosecution for bribery abroad (BREWSTER, 2017). Further, this enforcement strategy has been facilitated by the entry into force of the OECD Anti-Bribery Convention, which built international support for anti-foreign bribery laws and created opportunities for increased cooperation among countries in enforcing foreign bribery laws (BREWSTER, 2017, p. 1660).

It is important to note here that scholars have also shown that the increase in US prosecutions of foreign corporations for FCPA violations also tracks rising FCPA enforcement activity generally, as US FCPA enforcement against domestic corporations also increased markedly in the early 2000s (see e.g. CHRISTENSEN, MAFFETT and RAUTER, 2020). Here, one of the factors that scholars have highlighted to account for the increase in FCPA activity generally is better access to information about wrongdoing (PERLMAN and SYKES, 2018 , p. 10). The rise in negotiated settlements, like deferred prosecution agreements and non-prosecution agreements, which often includes corporate self-reporting (ASHCROFT and RATCLIFFE, 2012), also has likely contributed to the increase in FCPA prosecutions of foreign corporations. 
But while existing scholarship helps understand the motivation for why the US is generally willing to apply the FCPA to foreign corporations and the overall growth in US prosecutions of foreign corporations in the $21^{\text {st }}$ century, research is still emerging around the more granular questions of when the US deploys its expansive jurisdiction over particular foreign corporations for the bribery of foreign public officials. Here the section turns to consideration of scholarship on this more specific research question: in a world where bribery in international business remains rife, why does the US pursue certain foreign corporations for bribery abroad?

One of the simplest explanations for why and when the US targets foreign corporations for FCPA prosecutions is that it is simply following evidence of foreign bribery and focusing its attention on the most serious cases. Extending Putnam's regime protection argument discussed above, Putnam (2009 and 2016) suggests that the US should direct its resources to prosecute foreign corporations that pose the greatest risk to the anti-foreign bribery regulatory regime, which may well be foreign firms. As Rebecca Perlman and Alan Sykes argue, "having operated under FCPA requirements for decades, U.S. companies already tend to have strong compliance measures in place" (PERLMAN and SYKES, 2018, p. 24). Recent work by Nathan Jensen and Edmund Malesky shows that over time firms from OECD Convention countries, of which the US is a leading member, have become less likely to pay bribes to win business abroad (JENSEN and MALESKY, 2018). In addition, research by Stephen Choi and Kevin Davis on FCPA sanctions finds that "the egregiousness of the bribe and the extensiveness of the violation" influence the size of the financial penalty (CHOI and DAVIS, 2014, p. 411). A greater severity of wrongdoing could thus help to explain why foreign firms pay higher FCPA fines than US businesses (DIAMANT, SULLIVAN and SMITH, 2019; CHOI and DAVIS, 2014; GARRETT, 2011).

However, there is also growing research that questions the kind of neutrality in enforcement presumed by the regime protection argument and instead turns to what we can think of as political explanations for when the US prosecutes foreign corporations for foreign bribery. These political explanations go beyond the four corners of the FCPA and instead point to "extralegal" rationales for FCPA enforcement that further US strategic goals or reflect challenges of interstate cooperation. Some scholars have gone so far as to label the expansive application of the FCPA to foreign corporations as "a new form of American hegemony: 'prosecutorial imperialism'” (BARKOW and PERRY, 2014; see also SMITH and PARLING, 2012; GOLDEN, 2019). But while claims of prosecutorial imperialism are attentiongrabbing, it is too general a concept to help us understand when the US makes use of its expansive jurisdiction under the FCPA to prosecute foreign corporations. More fruitful is recent scholarship that approaches the political determinants of expansive US law enforcement as an open empirical question, exploring the conditions under which US prosecutors elect to exercise their jurisdiction over foreign corporations and whether and when these political factors influence the outcome of proceedings. 
More specifically, existing scholarship points us to four potential political drivers for FCPA prosecution of foreign corporations: economic interest, altruism, coordination, and spillover (CHOI and DAVIS, 2014; DAVIS, 2012; KACZMAREK and NEWMAN, 2011). Existing research is strongest in supporting the latter three political explanations, as I describe below.

Economic interest suggests that the US prosecutes foreign businesses for FCPA violations in order to advance specific US business interests or US national economic interests more generally. This could take the form of US prosecutors targeting bribery by foreign firms when the bribery puts US firms at a disadvantage, such as the bribery of public officials in countries where US business are most heavily invested (CHOI and DAVIS, 2014, p. 414). Or we can even imagine a prosecution targeted at US competitors. Charles Smith and Brittney Parling argue that a common view of FCPA prosecution of foreign corporations abroad is that they are intended to further US business interests (SMITH and PARLING, 2012, p. 249). They point to the example of the FCPA action against the German car company Daimler and argue that "it is reasonable for a German business person to question why the US government devoted extensive resources for over half a decade to prosecute a German competitor of the major American automakers" (SMITH and PARLING, 2012, p. 249). An executive from the French power and transportation company Alstom, which was subject to a US FCPA prosecution in 2014 and record-breaking fine at the time, has written a recent book heavily criticizing the prosecution (PIERUCCI and ARON, 2020). The book argues that the Alstom prosecution was motivated by US national economic interests, including laying the groundwork for the company's acquisition by the American company General Electric (PIERUCCI and ARON, 2020).

Beyond these high-profile examples, however, there are over a hundred other foreign corporations that have also been subject to US prosecution. These additional cases cross a wide range of industries with varied market concentrations and geographic footprints, making it challenging to draw an overt connection to US national economic interest. In their examination of variation in the level of sanctions in FCPA cases, Choi and Davis find no support for their hypothesis that FCPA sanctions are higher when involving bribery of public officials of countries where US business is highly invested, suggesting that, at least on this measure, prosecutors are not discriminating among foreign corporations based on national economic interest (CHOI and DAVIS, 2014, p. 440).

Another explanation for how and when the US exercises its expansive jurisdiction over foreign corporations focuses on the country whose public official was bribed. Research has shown that countries with high levels of corruption are more frequently the subject of FCPA prosecution (MCLEAN, 2012). In their work, Choi and Davis take this further and find evidence that corporations receive higher FCPA penalties when the bribery involves public officials in states with weak anti-corruption institutions (CHOI and DAVIS, 2014). As the authors put it, FCPA enforcement actions may be "altruistic," seeking to correct for 
the "shortcomings" of the state that had its public officials bribed (CHOI and DAVIS, 2014, p. 410). Here the US, which has the resources, experience, and institutional capacity to prosecute foreign bribery, may be using its expansive jurisdiction to prosecute bribery in international business that would otherwise go unpunished. Despite the label of "altruistic," it is important to note that the US prosecution of foreign corporations based on consideration of the host state is not necessarily at odds with US self-interest. As discussed earlier, it was the US, after all, that created anti-foreign bribery laws and oversaw their multilateralization, not purely out of goodwill, but also to ensure that businesses did not interfere with US foreign policy and to protect a global economy where the US has long been at the helm (KOEHLER, 2012; see also DAVIS, 2012).

This research focused on high corruption levels and institutional weaknesses of the host state aligns with a related area of scholarship that documents how increasing the number of anti-corruption institutions with responsibility for anti-bribery enforcement can improve accountability. Recent work by Mariana Prado and Raquel de Mattos Pimenta (2021) examines several bribery cases within Brazil and finds evidence that the presence of civil, criminal, and administrative anti-bribery institutions creates multiple pathways to accountability, which may be beneficial for enforcement under conditions of systemic corruption. Other scholarship considers institutional multiplicity in a transnational context of anti-bribery enforcement. According to the "institutional complementarity theory," when local anti-corruption institutions are unable to effectively address corruption, foreign laws and courts "can bring to the table valuable resources that local institutions are unable to match" (DAVIS, JORGE and MACHADO 2015, p. 668; see also DAVIS, 2010; ROSE-ACKERMAN and CARRINGTON, 2013; HOCK, 2019, p. 8; BREWSTER and ORTIZ, 2020). Kevin Davis, Guillermo Jorge, and Maíra Machado (2015) draw on case studies of transnational anti-bribery enforcement actions in Brazil and Argentina to find that foreign institutions were able to help overcome limitations of local institutions.

Characteristics of foreign corporations' home states can also ground explanations for when the US exercises its expansive jurisdiction over foreign bribery. One important variable that scholarship has identified here is affinity between the US and the corporation's home state. Scholars have argued that states are more willing to expansively assert their own laws when the impact of doing so will be felt by a like-minded country that shares similar legal standards and values (SLAUGHTER, 2003; PUTNAM, 2009). In addition, research has found that states are more likely to enter mutual legal assistance agreements with countries that share similar legal institutions (EFRAT and NEWMAN, 2018), which furthers prospects for cooperation among like-minded countries.

In complex cross-border criminal investigations like those of foreign bribery, cooperation from the corporation's home state can be crucial in obtaining evidence or accessing witnesses. Choi and Davis's work finds that the presence of a mutual legal assistance treaty with a corporation's home country is associated with a greater sanction on foreign corporations for bribery abroad (CHOI and DAVIS, 2014; see also MCLEAN, 2012). Whether US prosecutors 
anticipate cooperation from the corporation's home country is likely a significant consideration in commencing an FCPA prosecution.

Notably, ease of cooperation among like-minded states is promising to explain the geographic clustering of foreign corporations prosecuted for FCPA violations among OECD Anti-Bribery Convention countries. This clustering is particularly surprising given Jensen and Malesky's research that finds that firms from OECD Convention states have become less likely to engage in foreign bribery, while firms from non-OECD Convention states have become more likely to do so (JENSEN and MALESKY, 2018; CHAPMAN et al., forthcoming). While this would lead us to expect more expansive applications of the FCPA against foreign corporations from non-OECD countries, one reason why we may nevertheless see more frequent prosecutions of corporations from OECD countries is that these are countries that share similar legal standards and values with the US and have established practices of information sharing. For instance, Australia, Canada, the United Kingdom, and the US are members of the International Foreign Bribery Task Force, which is intended to facilitate cooperation among law enforcement agencies in these countries (FERGUSON, 2018, p. 552).

Moreover, ease of cooperation can help to account for a growing trend of "coordinated resolutions" or "global settlements," where enforcement agencies in multiple countries, including the US, simultaneously negotiate and enter into a resolution of foreign bribery allegations with a corporation. Many of the most prominent recent FCPA actions against foreign corporations have taken the form of global settlements, and have involved cooperation between US authorities and their counterparts in a handful of OECD Anti-Bribery Convention countries. One notable example is the coordinated resolution with Rolls-Royce, a UK aerospace and engineering company. In 2017, US prosecutors fined Rolls-Royce $\$ 170$ million for the bribery of public officials in Brazil, Kazakhstan, Azerbaijan, Angola, and Iraq (DOJ 2017). In setting this fine, US prosecutors took account of a settlement that Rolls-Royce reached that same day with UK prosecutors for almost $\$ 600$ million relating to the bribery of public officials in China, India, Indonesia, Malaysia, Nigeria, Russia and Thailand (DOJ 2017). In addition to the UK, the US has conducted coordinated resolutions with Brazilian, Dutch, French, German, and Swiss prosecutors. ${ }^{\mathbf{5}}$

Another home state characteristic that existing scholarship suggests is relevant to US FCPA prosecution of foreign corporations, and the last political explanation to consider, is the home state's enforcement of its own foreign bribery laws. That is, whether the home state enforces anti-foreign bribery laws could also influence US decision-making on whether to pursue an FCPA prosecution of a particular corporation. In their work, Sarah Kaczmarek and

5 US global settlement for FCPA violations include coordinated resolutions for Siemens (Germany, 2008), Embraer (Brazil, 2016), Odebrecht and Braskem (Brazil and Switzerland, 2016), VimpelCom (Netherlands, 2016), Telia (Netherlands, 2017), and Société Générale (France, 2018). 
Abraham Newman find evidence of a "spillover effect," where the US prosecution of a foreign corporation makes the home state of that corporation more likely to increase the enforcement of its own anti-foreign bribery laws (KACZMAREK and NEWMAN, 2011). This suggests that the US prosecutes foreign corporations from particular jurisdictions in order to spur increased anti-foreign bribery enforcement in those countries. At least in the initial years of US prosecution of foreign corporations for FCPA violation, this too can help to explain a focus on foreign corporations based in home states of OECD Anti-Bribery Convention countries, particularly those that were slow to start enforcing their own anti-foreign bribery laws once the Convention entered into force. Further, the influence of US prosecution on the home states to foreign defendants may include not just increased enforcement, but also related law reforms. For instance, the strengthened French anti-foreign bribery laws introduced in 2017 with Sapin II followed multiple US prosecutions of French firms for bribery of foreign public officials, including Alstom.

In sum, the growing and active research agenda on the expansive application of US law and specifically on the FCPA has helped to generate explanations and evidence of what influences the exercise of the FCPA's expansive jurisdiction over foreign corporations. This includes both explanations that rely on the nature of the wrongdoing, where US prosecutors prioritize the most egregious violations of anti-foreign bribery laws, as well as explanations that point to political determinants of the expansive application of the FCPA. Before turning to discuss how scholars can further investigate these explanations, I consider next several challenges for future research to bear in mind.

\section{Research Challenges}

Studying bribery in international business presents several research challenges, as does attempting to understand when the US exercises its expansive jurisdiction over foreign corporations for bribery abroad. As a criminal activity that benefits both the bribe-payer and the bribe-taker, there is little incentive for foreign bribery to be disclosed, let alone systematically reported. We know from DOJ and SEC press releases which FCPA prosecutions against foreign corporations have been resolved. But we do not know the denominator and universe of foreign bribery cases from which US prosecutions are drawn. This means that we are overlooking instances of foreign bribery that have gone undetected. Existing scholarship has attempted to address this challenge by taking into account the corruption levels in a given country through measurements like the World Bank's Control of Corruption indicator (e.g. CHOI and DAVIS, 2014, p. 428-30; MCLEAN, 2012, p. 1990). Even more challenging for research on the question of what drives US prosecution of foreign corporations is that we are also unaware of what allegations of foreign bribery come to the attention of US prosecutors but are not pursued. Much of the early decision-making by investigators and prosecutors as to whether to proceed with an FCPA enforcement action against a foreign corporation is never publicly reported. For 
cases that are prosecuted, the press releases by the DOJ and SEC may only tell part of the story of the investigation, prosecution, and company wrongdoing.

In addition, if research on FCPA prosecution of foreign corporations is ultimately interested in questions about the expansive application of domestic law, we encounter a conceptual problem of how to define the phenomenon of interest. Not all foreign corporations are "foreign" in the same way, and not all US prosecutions of foreign corporations are similarly characterized as an expansive application of US law. Consider, for instance, the 2009 charges by US prosecutors of the British company AGCO Limited for conspiracy to violate the FCPA in the bribery of Iraqi public officials (DOJ 2009). AGCO Limited is incorporated and headquartered in the United Kingdom, and is a wholly-owned subsidiary of an American agricultural supply company, AGCO Corporation, based in Duluth, Georgia. AGCO Limited resolved the charges against it through payment of a $\$ 1.6$ million dollar fine and a deferred prosecution agreement - which it entered into with US prosecutors and its US corporate parent (DOJ 2009). While AGCO Limited is a foreign corporation, it operates as part of a US business and participated in the FCPA settlement with a US parent company. All that to say, while AGCO Limited is a foreign corporation that was prosecuted for violating the FCPA, we may well ask if it should be part of the universe of cases in a project concerned with the expansive application of domestic law.

Further, the varied jurisdictional grounds of FCPA prosecutions of foreign corporations give rise to another conceptual issue relating to "foreignness" and the kind of expansive application of national law that we are interested in. For instance, SEC prosecutions of foreign issuers for violations of the accounting provisions and DOJ prosecutions of foreign non-issuer corporations captured by a broad reading of what counts as an "act in furtherance" of foreign bribery in the United States may well warrant examination as different types or degrees of the expansive application of US law.

This research also faces an important level of analysis issue in that it can impute political rationales of the state to actions of federal prosecutors. It is federal prosecutors within the DOJ and SEC that make decisions on whether to pursue an FCPA action against a particular corporation. This raises a classic principal-agent problem and points to the potentially divergent interests of the legislators who created the FCPA and the prosecutors who enforce it (e.g. LOWI, 1979; NISKANEN, 1971). Specifically, this raises the question of whether it is reasonable to assume that prosecutors even engage with the kinds of political influences on expansive enforcement described by existing research (see Section 2 supra). Still, federal prosecutors are not immune from politics; and the executive branch plays an important agenda-setting role in all kinds of federal law enforcement, including the FCPA. ${ }^{6}$ Further, there

6 One need only consider recent controversies, such as former President Trump's assertions of influence in cases stemming from the Russia inquiry, to underscore the relationship between politics and federal law enforcement (see generally GREEN and ROIPHE 2018; KOH, forthcoming). 
is no reason to expect resistance among prosecutors from bringing actions against foreign corporations that fall within the FCPA's ambit. In fact, such cases may be attractive to prosecutors: scholars have suggested that incentives facing federal prosecutors encourage ambitious applications of the FCPA to build experience in complex cases and further their own careers both within and outside of government. Pierre-Hugues Verdier captures this in his recent study of US prosecutions of global banks: "In sum, prosecutors' incentives - whether they arise from personal motivations, political accountability, or personal ambition-generally encourage aggressive investigation and prosecution of criminal cases" (VERDIER, 2020, p. 26) (see also BREWSTER and BUELL, 2017; PERLMAN and SYKES, 2018, p. 10). Which is to say, while the level of analysis issue of imputing state rationales to individual prosecutors remains, we can imagine both how politics could influence prosecutorial decisions, and how incentives facing prosecutors might align with political explanations for the expansive application of the FCPA.

\section{Future Research}

There are several promising avenues for further research that are poised to address some of these research challenges and help us better understand the application of the FCPA to foreign corporations. To start, new and better data has the potential to add to this research agenda. Anti-foreign bribery law and enforcement is still relatively new, even in the US, and a needed next step for researchers is to update some of these early findings. For instance, the findings of Kaczmarek and Newman on the spillover effect of US prosecution of foreign corporations rests on data from 1998 to 2008 (KACZMAREK and NEWMAN, 2011), capturing the beginning of regular FCPA prosecutions of foreign corporations and the first decade where anti-foreign bribery laws in other countries were commonplace. Recent scholarship that investigates this same phenomenon using another decade of anti-foreign bribery law enforcement finds a much smaller effect of US FCPA prosecution of foreign corporations on foreign bribery enforcement in the defendant's home state and reaches a more cautious conclusion about the influence of the expansive application of the FCPA (ACORN and ALLEN, 2019). Similarly, Choi and Davis's examination of variation in the level of FCPA sanctions only goes through 2011, creating an opportunity for scholars today to explore more recent trends in the determinants of FCPA sanctions. This growing data also gives scholars an opportunity to further explore another important research agenda: the consequence of the expansive application of the FCPA, including on foreign direct investment and corporate compliance policies (ALLEN, 2021; CHRISTENSEN, MAFFETT and RAUTER, 2020).

An important task for the research agenda being explored in this article - the drivers of US FCPA prosecution of foreign corporations - is to more squarely examine what leads prosecutors to make particular decisions as to whether to pursue a case against a given foreign 
corporation. Many of the potential explanations of US FCPA prosecution of foreign corporations discussed in Section 2 are based on research that examines FCPA sanctions. But even if foreign corporations are systematically treated differently in the FCPA sanctions imposed, this is a distinct question from the calculus that guides prosecutors in commencing an action against a foreign corporation in the first place. As the discussion above noted, what influences US prosecutorial decision-making is a difficult question to study given that persistent data challenges may well prevent us from knowing the universe of potential cases that come to the attention of FCPA prosecutors.

Despite these research difficulties there are potential ways forward, and here qualitative research may prove fruitful. Existing research, like that of Davis, Jorge, and Machado (2015), has shown the value of carefully-chosen comparative case studies in examining transnational bribery enforcement. Similar case studies could help scholars better understand the conditions under which US prosecutors are likely to exercise jurisdiction over foreign corporations. For example, scholars could examine cases where the US could have plausibly asserted jurisdiction over foreign bribery crimes, but did not pursue a case. Media reports, foreign bribery cases in other jurisdictions, and debarment procedures at the multilateral development banks could help identify potential case studies. Further, case studies of different kinds of "foreign" defendants, as discussed in Section 3, could help to isolate whether particular explanations for the US expansive application of the FCPA are more likely for certain kinds of non-American defendants than others.

In addition, interview research can advance this research agenda. Interviews with current and former prosecutors would provide direct evidence of the decision-making process by US authorities in bringing FCPA cases against foreign corporations. While current prosecutors may be reluctant to speak about the determinants of cases, former prosecutors are likely to be less encumbered. Further, researchers could also make use of vignettes"hypothetical scenarios" that are presented to an interviewee and that the interviewee is asked to respond to by "drawing on his or her own experience" (JENKINS et al., 2010, p. 175). This would avoid encroaching on any privileged information relating to particular cases and could enable the interviewee to speak more freely. In addition, research could also benefit from interviews with defense counsel to gauge how lawyers advising corporations weigh risks and assess the likelihood of prosecutions by US authorities. Here the use of vignettes in the interviews could also facilitate more fulsome responses and avoid discussing particular cases. Researchers could opt instead to administer surveys to prosecutors and defense counsel using vignettes or other survey techniques, like a list-experiment, which is useful to collect information about a sensitive topic. Recent scholarship by Jensen and Malesky made use of a list-experiment to gauge firm-level propensity to bribery in international business (JENSEN and MALESKY, 2018).

These qualitative research techniques can help scholars further understand the potential explanations for US FCPA prosecution of foreign defendants. For instance, closely examining 
bilateral relationships between the US and other countries can help move beyond formal indicators of international legal cooperation and help us to better assess how prospects for cooperation influence FCPA prosecution of foreign corporations. Current research has focused on formal arrangements of legal cooperation, like mutual legal assistance treaties or memoranda of understanding among securities regulators, but may only be capturing a portion of the importance of legal cooperation from other states. In practice, the presence of a formal arrangement for legal cooperation may be only a starting point. For instance, the US and China have had a mutual legal assistance treaty in place since the late 1990s, but legal cooperation between the two countries has nonetheless been fraught. It is notable that when it comes to the FCPA, the US has prosecuted only a handful of Chinese companies for foreign bribery abroad, despite China's growing presence in the international economy where risks of foreign bribery persist (see ROSS, 2018). Interviews with investigators and prosecutors on the practice of international legal cooperation and case studies of past efforts of cooperation can help to shed light on the process of cross-border evidence gathering between particular countries and how it may be influencing prosecutorial decision-making when it comes to foreign corporations.

Closer qualitative research is also well-positioned to adjudicate among potential explanations of US FCPA enforcement against foreign defendants, as well as to consider how the various potential explanations for the expansive enforcement of the FCPA may interact. As Section 2 has mapped out, there are multiple reasons why a particular foreign corporation may draw the attention of US prosecutors. The company may be suspected of engaging in an egregious violation of anti-foreign bribery laws that threatens fair markets, involved in the bribery of public officials in a country with systemic corruption and weak anti-corruption institutions, or based in a jurisdiction with an established relationship of legal cooperation with the US or weak anti-foreign bribery enforcement of its own. Research that specifies the empirical implications of each contending explanation and assesses it against newly generated data can shed light on whether one explanation outweighs others. This can also help us to understand how these explanations may trade off, for instance, under what conditions prosecutors may pursue a case against a foreign corporation, even if the home state may be unlikely to cooperate.

In short, while this is a challenging area of research, the expansive application of the FCPA nonetheless offers many promising avenues for future research for scholars interested in the role of national law in international law and politics.

\section{CONCLUSIONS}

In a globalized economy full of international businesses and cross-border dealings, it is important for scholars to recognize that national law and national law enforcement are nonetheless still significant, and all the more so when applied by a powerful state like the US to govern 
conduct that occurs largely outside its borders. This article has examined a particular instance of such expansive national law enforcement, considering the application of US anti-foreign bribery law to foreign corporations and documenting a growing research agenda that seeks to understand the US use of its expansive FCPA jurisdiction over foreign corporations. While there are significant challenges in this research, there is also much potential to deepen our understanding of when and how the US uses the FCPA to govern international business and further explore the role of national law and law enforcement in foreign policy and international politics.

\section{ACKNOWLEDGEMENTS}

The author would like to thank the editors of the special issue, Ashley Armstrong, Danielle Gilbert, Ryan Liss, Stephen Koh, David Stewart, Rachel Whitlark, and two anonymous reviewers for insightful comments and suggestions on earlier drafts. Her gratitude as well to participants in the American Society of International Law's Research Forum and the Law and Systemic Corruption Conference for their generous feedback.

\section{REFERENCES}

ABBOTT, Kenneth W.; SNIDAL, Duncan. Values and Interests: International Legalization in the Fight against Corruption. The Journal of Legal Studies, v. 31, n. S1, p. 141-177, 2002.

ACORN, Elizabeth; ALLEN, Michael O. Extra-Territorial Law Enforcement as a Mechanism of Policy Diffusion: A Reappraisal of the OECD Anti-Bribery Convention. In: American Political Science Association Conference. Washington, D.C., 2019.

ALLEN, Michael O. The Corruption Penalty: Global Commerce, Bribery, and the Growing Fear of Getting Caught. In: International Studies Association Annual Conference, 2021.

ASHCROFT, John; RATCLIFFE, John. The Recent and Unusual Evolution of an Expanding FCPA. Notre Dame Journal of Law, Ethics \& Public Policy, v. 26, p. 25-38, 2012. 
BACH, David; NEWMAN, Abraham. Domestic Drivers of Transgovernmental Regulatory Cooperation. Regulation \& Governance, v. 8, n. 4, p. 395-417, 2014.

BARKOW, Anthony S.; PERRY, Anne Cortina. American Prosecutorial Imperialism? Litigation, v. 41, p. 28-33, 2014.

BREUER, Lanny. Assistant Attorney General Lanny A. Breuer Speaks at the 24th National Conference on the Foreign Corrupt Practices Act, Fort Washington, MD. November 16, 2010. Available at: https: //www. justice.gov/opa/speech/assistant-attorney-general-lanny-breuer-speaks-24th-national-conferenceforeign-corrupt.

BREWSTER, Rachel. Enforcing the FCPA: International Resonance and Domestic Strategy. Virginia Law Review, v. 103, p. 1611-1682, 2017.

BREWSTER, Rachel; BUELL, Samuel. The Market for Global Anticorruption Enforcement. Law and Contemporary Problems, v. 80, p. 193-214, 2017.

BREWSTER, Rachel; DRYDEN, Christine. Building Multilateral Anticorruption Enforcement: Analogies between International Trade \& Anti-Bribery Law. Virginia Journal of International Law, v. 57, p. 221-263, 2018.

BREWSTER, Rachel; ORTIZ, Andres. Never Waste A Crisis: Anticorruption Reforms in South America. Virginia Journal of International Law, v. 60, p. 531-570, 2020.

CARTER, Jimmy. Foreign Corrupt Practices and Investment Disclosure Bill Statement on Signing S. 305 into Law. December 20, 1977.

CASSIN, Harry. Wall Street Bank Earns Top Spot on FCPA Blog Top Ten List. The FCPA Blog (blog). October 26, 2020a. Available at: https: / fcpablog.com/2020/10/26/wall-street-bank-earns-topspot-on-fcpa-blog-top-ten-list/.

CASSIN, Harry. The FCPA Unfairly Punishes Foreign Companies. Or Does It? The FCPA Blog (blog). November 19, 2020b. Available at: https: / fcpablog.com/2020/11/19/the-fcpa-unfairly-punishesforeign-companies-or-does-it/.

CHAPMAN, Terrence L.; JENSEN, Nathan M.; MALESKY, Edmund J.; WOLFORD, Scott. "Leakage" in International Regulatory Regimes: Did the OECD Anti-Bribery Convention Increase Bribery? Quarterly Journal of Political Science, v. 43, forthcoming. 
CHOI, Stephen J.; DAVIS, Kevin E. Foreign Affairs and Enforcement of the Foreign Corrupt Practices Act. Journal of Empirical Legal Studies, v. 11, n. 3, p. 409-445, 2014.

CHRISTENSEN, Hans B.; MAFFETT, Mark; RAUTER, Thomas. Policeman for the World: The Impact of Extraterritorial FCPA Enforcement on Foreign Investment and Internal Controls, 2020.

DAVIS, Kevin E. Does the Globalization of Anti-Corruption Help Developing Countries. In: FAUNDEZ, Julio; TAN, Celine (ed.). International Economic Law, Globalization and Developing Countries. Northhampton: Edward Elgar, 2010. p. 283-306.

DAVIS, Kevin E. Why Does the United States Regulate Foreign Bribery: Moralism, Self-Interest, or Altruism? New York University Annual Survey of American Law, v. 67, p. 497-512, 2012.

DAVIS, Kevin E.; JORGE, Guillermo; MACHADO, Maíra R. Transnational Anticorruption Law in Action: Cases from Argentina and Brazil. Law \& Social Inquiry, v. 40, n. 3, p. 664-699, 2015.

DEPARTMENT OF JUSTICE. Siemens $A G$ and Three Subsidiaries Plead Guilty to Foreign Corrupt Practices Act Violations. December 15, 2008. Available at: https://www.justice.gov/archive/opa/pr/2008/ December/08-crm-1105.html.

DePARTMENT OF JUSTICE. AGCO Corp. to Pay $\$ 1.6$ Million in Connection with Payments to the Former Iraqi Government Under the U.N. Oil-For-Food Program. September 30, 2009. Available at: https: / /www. justice.gov/opa/pr/agco-corp-pay-16-million-connection-payments-former-iraqi-government-underun-oil-food.

DEPARTMENT OF JUSTICE. Rolls-Royce Plc Agrees to Pay \$170 Million Criminal Penalty to Resolve Foreign Corrupt Practices Act Case. January 17, 2017. Available: https://www.justice.gov/opa/pr/rolls-royceplc-agrees-pay-170-million-criminal-penalty-resolve-foreign-corrupt-practices-act.

DEPARTMENT OF JUSTICE and SECURITIES AND EXCHANGE COMMISSION. A Resource Guide to the U.S. Foreign Corrupt Practices Act, 2020.

DIAMANT, Michael S.; SULLIVAN, Christopher W. H.; SMITH, Jason H. FCPA Enforcement Against U.S. and Non-U.S. Companies. Michigan Business \& Entrepreneurial Law Review, v. 8, n. 2, p. 353-380, 2019.

EFRAT, Asif; NEWMAN, Abraham L. Deciding to Defer: The Importance of Fairness in Resolving Transnational Jurisdictional Conflicts. International Organization, v. 70, n. 2, p. 409-441, 2016. 
EFRAT, Asif; NEWMAN, Abraham L. Divulging Data: Domestic Determinants of International Information Sharing. The Review of International Organizations, v. 13, n. 3, p. 395-419, 2018.

FARRELL, Henry; NEWMAN, Abraham L. The New Interdependence Approach: Theoretical Development and Empirical Demonstration. Review of International Political Economy, v. 23, n. 5, p. 713-736, 2016.

FARRELL, Henry; NEWMAN, Abraham L. Weaponized Interdependence: How Global Economic Networks Shape State Coercion. International Security, v. 44, n. 1, p. 42-79, 2019.

FERGUSON, Garry. Global Corruption: Law, Theory and Practice. University of Victoria, 2018.

GARRETT, Brandon L. Globalized Corporate Prosecutions. Virginia Law Review, v. 97, n. 8, p. 1775 $1875,2011$.

GOLDEN, Nathan. Conspicuous Prosecution in the Shadows: Rethinking the Relationship Between the FCPA's Accounting and Anti-Bribery Provisions. Iowa Law Review, v. 104, p. 891-925, 2019.

GREEN, Bruce A.; ROIPHE, Rebecca. Can the President Control the Department of Justice? Alabama Law Review, v. 70, n. 1, p. 1-76, 2018.

GUTTERMAN, Ellen. Easier Done Than Said:Transnational Bribery, Norm Resonance, and the Origins of the US Foreign Corrupt Practices Act. Foreign Policy Analysis, v. 11, n. 1, p. 109-128, 2015.

HOCK, Branislav. Extraterritoriality and International Bribery: A Collective Action Perspective. London: Routledge, 2019.

IRANI, Freya. Beyond de Jure and de Facto Boundaries: Tracing the Imperial Geographies of US Law. European Journal of International Relations, v. 26, n. 2, p. 397-418, 2020.

JENKINS, Nicholas et al. Putting It in Context: The Use of Vignettes in Qualitative Interviewing. Qualitative Research, v. 10, n. 2, p. 175-198, 2010.

JENSEN, Nathan M.; MALESKY, Edmund J. Nonstate Actors and Compliance with International Agreements: An Empirical Analysis of the OECD Anti-Bribery Convention. International Organization, v. 72, n. 1, p. 33-69, 2018.

KACZMAREK, Sarah C.; NEWMAN, Abraham L. The Long Arm of the Law: Extraterritoriality and the National Implementation of Foreign Bribery Legislation. International Organization, v. 65, n. 4, p. 745-770, 2011. 
KOEHLER, Mike. The Story of the Foreign Corrupt Practices Act. Ohio State Law Journal, v. 73, p. 929-1013, 2012.

KOEHLER, Miles. The Facade of FCPA Enforcement. Georgetown Journal of International Law, v. 41, p. 907-1009, 2009.

$\mathrm{KOH}$, Steven Arrigg. Foreign Affairs Prosecutions. New York University Law Review, v. 94, p. 340-401, 2019.

$\mathrm{KOH}$, Steven Arrigg. The Criminalization of Foreign Relations. Fordham Law Review, forthcoming.

LOWI, Theodore J. The End of Liberalism: The Second Republic of the United States. New York, 1979.

MCLEAN, Nicholas M. Cross-National Patterns in FCPA Enforcement. TheYale Law Journal, v. 121, n. 7, p. 1970-2012, 2012.

NISKANEN, Jr., William A. Bureaucracy and Representative Government. Transaction Publishers, 1971.

OECD. 2019 Enforcement of the Anti-Bribery Convention, 2020. Available at: http://www.oecd. org/daf/anti-bribery/OECD-Anti-Bribery-Convention-Enforcement-Data-2020.pdf.

PERLMAN, Rebecca L.; SYKES, Alan O. The Political Economy of the Foreign Corrupt Practices Act: An Exploratory Analysis. Journal of Legal Analysis, 2018.

PIERUCCI, Frédéric; ARON, Matthieu. The American Trap: My Battle to Expose America's Secret Economic War against the Rest of the World. London: Hodder \& Stoughton, 2020.

PRADO, Mariana Mota, and PIMENTA, Raquel de Mattos. Systemic Corruption and Institutional Multiplicity: A Complex Relationship as Illustrated by Brazilian Examples, 2021.

PUTNAM, Tonya L. Courts without Borders: Domestic Sources of U.S. Extraterritoriality in the Regulatory Sphere. International Organization, v. 63, p. 459-490, 2009.

PUTNAM, Tonya L. Courts without Borders: Law, Politics, and US Extraterritoriality. Cambridge: Cambridge University Press, 2016.

RAUSTIALA, Kal. Does the Constitution Follow the Flag? The Evolution of Extraterritoriality in American Law. Oxford: Oxford University Press, 2011. 
RICHARDSON, Elliot. Secretary of Commerce Elliot Richardson to Senator William Proxmire, June $11,1976$.

ROSE-ACKERMAN, Susan; CARRINGTON, Paul D. (ed.). Anti-Corruption Policy: Can International Actors Play a Constructive Role? Durham (North Carolina): Carolina Academic Press, 2013.

ROSS, Eleanor. Increasing United States-China Cooperation on Anti-Corruption: Reforming Mutual Legal Assistance. The GeorgeWashington Law Review, v. 86, n. 3, p. 839-868, 2018.

SLAUGHTER, Anne-Marie. A Global Community of Courts. Harvard International Law Journal, v. 44, p. 191-220, 2003.

SMITH, Charles F.; PARLING, Brittany D. “American Imperialism”: A Practitioner's Experience with Extraterritorial Enforcement of the FCPA. The University of Chicago Legal Forum, p. 237-257, 2012.

SPAHN, Elizabeth K. Implementing Global Anti-Bribery Norms: From the Foreign Corrupt Practices Act to the OECD Anti-Bribery Convention to the UN Convention Against Corruption. Indiana International \& Comparative Law Review, v. 23, p. 1-33, 2013.

TARULLO, Daniel. The Limits of Institutional Design: Implementing the OECD Anti-Bribery Convention. Virginia Journal of International Law, v. 44, p. 655-710, 2004.

UROFSKY, Phil; MOON, Hee Won. A Resource Guide to the Foreign Corrupt Practices Act: The US Government's Perspective on Enforcing the FCPA. In: PIETH, Mark; LOW, Lucinda A.; BONUCCI, Nicola (ed.). The OECD Convention on Bribery: A Commentary. Cambridge: Cambridge University Press, 2013. p. 684-724.

VERDIER, Pierre-Hugues. Global Banks on Trial: U.S. Prosecutions and the Remaking of International Finance. Oxford: Oxford University Press, 2020.

WOUTERS, Jan; RYNGAERT, Cedric; CLOOTS, Ann Sofie. The International Legal Framework against Corruption: Achievements and Challenges. Melbourne Journal of International Law, v. 14, p. 1 76, 2013. 


\section{HOW TO QUOTE THIS ARTICLE:}

ACORN, Elizabeth. Law and Politics in FCPA Prosecutions of Foreign Corporations. Revista Direito GV, São Paulo, v. 17, n. 2, maio/ago. 2021, e2124. https://doi.org/10.1590/23176172202124

\section{Elizabeth Acorn}

Assistant Professor of Political Science at the University of Toronto. Mars Brothers Postdoctoral Fellow IN Business Ethics at Yale University. PhD in Government at CORNELL UNIVERSITY. LAW DEGREE FROM THE UNIVERSITY OF TORONTO. elizabeth.acornautoronto.ca 